(C) 2017

Ляшенко С. В., кандидат технічних наук,

Пошивайло Ю. О., магістр

Полтавська державна аграрна академія

\title{
ВДОСКОНАЛЕННЯ МАШИН ДЛЯ ВИГОТОВЛЕННЯ ПАЛИВНОГО МАТЕРІАЛУ НЕОБХІДНОЇ ФРАКЦІЇ ДЛЯ ПОБУТОВОГО ВИКОРИСТАННЯ
}

\author{
Рецензент - доктор технічних наук, професор О. М. Костенко
}

Розглянуто використання паливного матеріалу в умовах особистого селянського господарства. Проведений аналіз ефективності різних видів біопалива. Обгрунтовано доиільність використання деревної тріски в якості альтернативного біопалива. Наведено аналіз конструкиій промислових машин для виготовлення тріски. Встановлено, щуо для проектування побутового тріскорізу в його конструкиії слід передбачити дисково-ножовий робочий орган та калібрувальне решето.

Ключові слова: біопаливо, транули, деревна тріска, тріскоріз, машина, конструкиія, технологія виробництва.

Постановка проблеми. Щороку в лісах Полтавщини росте на 1/3 більше дерев, ніж ми використовуємо. Також 3 кожним роком накопичуються відходи деревини під час лісозаготівлі. Деревина та iï відходи є сировиною, яку можна переробляти на паливну тріску. Тому тріска відноситься до кризостійкого паливного матеріалу. Для виробництва тріски, перш за все, використовуються дерева, пошкоджені під час буревіїв, гілки, а також відходи промислової заготівлі деревини.

Одне 3 найбільш актуальних питань, що виникає після того, як ліс зрубаний: «Що робити 3 відходами?» Останнім часом відбувається швидкий перехід до використання біомаси як палива. Тверде біопаливо відіграє істотну роль в енергозабезпеченні промислово розвинених країн: у США його частка становить близько $4 \%$, у Данії - $6 \%$, у Канаді - 7 \%, в Австрії - 14 \%, у Швеції - $16 \%$ від загального споживання первинних енергоресурсів [2].

Ефективність переробки біомаси в енергетичну продукцію досягається лише за раціональних параметрів технологічних процесів і машин, які іiі виконують.

Аналіз останніх досліджень та публікацій, у яких започатковано розв'язання проблеми. Тріска - основний продукт подрібнення деревини. Розрізняють технологічну, зелену, паливну та декоративну тріску. Класифікація фракцій i властивостей тріски, як подрібненої деревини - визначаються дією декількох ГОСТів (ГОСТ 23246-78 і ГОСТ 18110-72). Нова офіційна нормативно-технічна документації в цій області регламентується ДСТУ ЕN 15234-4:2013 [4].

Аналізу технологій виробництва різних видів твердого біопалива присвячено роботи В. Думич, В. Бунецького, М. Габрель та інших $[1,2$, 3]. Узагальнюючи результати досліджень вчених, слід зазначити, що технології виробництва біопалива описані досить повно, але конструкції машин для його виготовлення постійно вдосконалюються.

Мета та завдання досліджень: запропонувати конструктивні особливості машини для виготовлення паливного матеріалу в умовах особистого селянського господарства. Для досягнення мети необхідно провести аналіз існуючих промислових засобів виготовлення паливного матеріалу. Виявити раціональні конструктивні елементи машин та адаптувати їх у конструкції дослідного зразка побутової машини 3 метою отримання паливного матеріалу необхідної фракції.

Результати дослідження. Сучасні котли забезпечують спалювання в автоматичному режимі різних видів твердого біопалива (гранул, пелет, тирси, деревної тріски, січки тощо) вологістю від $10 \%$ до $70 \%$ [5].

Певна вага одного й того ж матеріалу, в якому вигляді він би не був (подрібнений, спресований, гранульований тощо), має однакову теплотворність. Деякі із характеристик твердого біопалива (щільність, розміри частинок, форма поверхні) через подрібнення та ущільнення можуть бути змінені, проте його основні паливно-технологічні характеристики є незмінними. Енергетична цінність біопалива 3 певного матеріалу залежить лише від його вологості [6].

Гранули та пелети виготовляють методом пресування 3 відходів деревини (тирси, тріски), сільськогосподарських відходів (соломи і оболонок зернових культур, стебла кукурудзи та соняшника тощо) та біомаси енергетичних культур. Деякі виробники для продовження тривало- 


\section{TEХНIЧНI НАУКИ}

сті зберігання гранул використовують в'яжучі речовини, які часто містять фосфор. Під час спалювання сполуки фосфору попадають у димові гази і сприяють утворенню кислотних дощів i збільшують корозію димоходів. Тому краще використовувати гранули без в'яжучих речовин.

Виробництво гранул або пелет має значні недоліки, що знижує ефективність їх як палива. По-перше, для виготовлення пелет необхідна деревина високої якості із вмістом кори не більше $8 \%$ без гнилі і домішок хвої та листя. Такий матеріал ефективніше використати для виробництва меблів та іншої продукції, аніж спалювати. По-друге, виготовлення гранул - досить складний і енергоємний процес, обладнання має високу вартість. По-третє, найбільш значний недолік гранул - їх гігроскопічність.

Зазначені недоліки виробництва пелет стали причиною того, що деякі країни СС починають віддавати перевагу використанню деревної тріски та січки сільськогосподарських культур як палива.

Деревна тріска хоча й має меншу об’ємну теплотворність, ніж гранули, проте вона значно дешевша.

Виготовлення тріски здійснюється лише однією машиною - тріскорізом. Для зберігання щепитріски не потрібно спеціальних приміщень.

Деревну тріску виготовляють 3 усіх залишків лісозаготівлі та видалених деревних рослин в результаті санітарних рубок у лісових насадженнях та прорідження садків в особистих селянських господарствах. Матеріал для виготовлення тріски одержують в результаті звичайної експлуатації лісового господарства. Тріску також можна одержувати 3 деревних енергетичних рослин та деревних відходів деревообробних та меблевих підприємств. Існує кілька видів тріски (див. табл.).

Для виробництва тріски застосовують подрібнювальні машини-тріскорізи. Фірми пропонують машини мобільні (причіпні та самохідні) і стаціонарні $з$ приводом від електродвигуна 3 продуктивністю від 10 до $120 \mathrm{~m}^{3} /$ год, які можуть подрібнювати відходи лісозаготівлі (гілки, сучки тощо), лісопильних та деревообробних підприємств (обрізки тощо), а також матеріали, які підлягають утилізації (старі меблі, піддони, відходи будівництва та садівництва і ін.).

Для виготовлення тріски та забезпечення ii необхідної фракції, а саме по ГОСТ, нами проаналізовано конструкції наступних машин.

Українська компанія «ARPAL» пропонує «ЩЕПОРЕ3 МК-120ТР», який дає змогу без особливих зусиль переробляти стовбури дерев, крони, гілки, відходи деревообробної промисловості діаметром до 12 см на технологічну тріску розмірами 5-50 мм (рис. 1).

\section{Европейська класифікація деревної тріски}

\begin{tabular}{|l|c|c|c|}
\hline \multicolumn{1}{|c|}{ Фракція щепи, розмір } & Класифікація & $\begin{array}{c}\text { Вологість } \\
\text { тріски, } \%\end{array}$ & Класифікація \\
\hline Мілка фракція, довжина - до 3 cм & G30 & 20 & W20 \\
\hline Середня фракція, довжина -3-5 cм & G50 & 30 & W30 \\
\hline Велика фракція, довжина - до 5-10 см & G100 & & \\
\hline
\end{tabular}

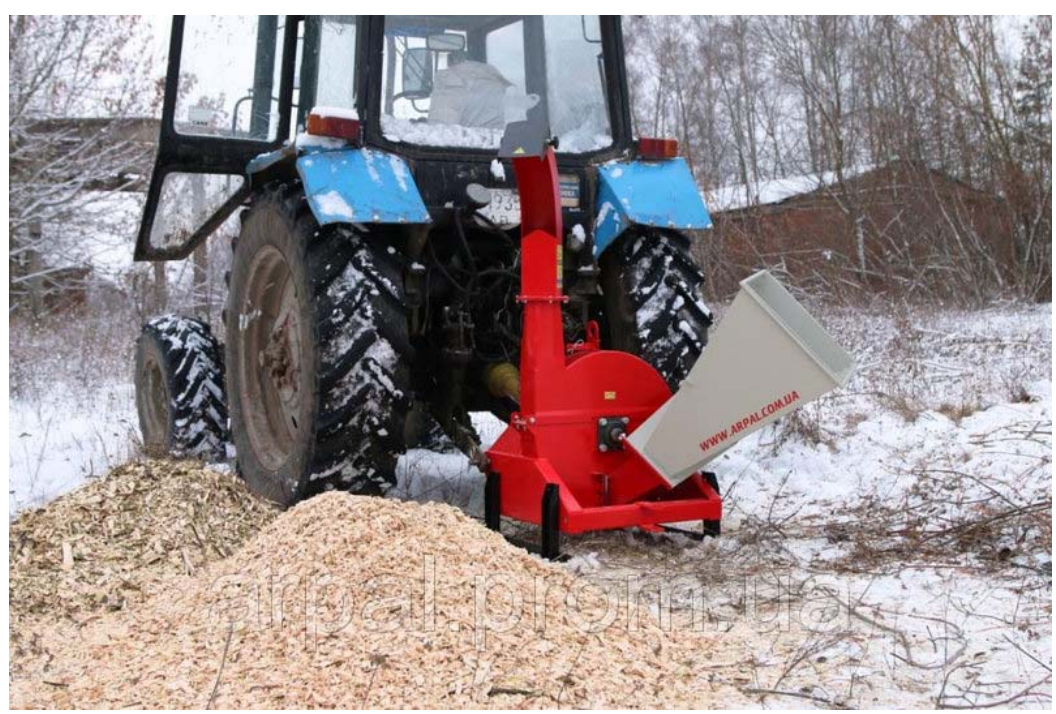

Рис. 1. Щепорез МК-120TP 
Але вагомим недоліком є вартість установки, вона завелика (орієнтовно 1500 доларів), як для використання в умовах особистого селянського господарства. Машина агрегатується 3 енергетичним засобом (трактором), певної потужності від валу відбору потужності, що в свою чергу створює додаткові витрати.

Особливістю конструкції подрібнювача є дисково-ножевий різальний апарат, що забезпечує подрібнення матеріалу на задану фракцію.

Розглянемо деревопереробну машину спільного українсько-німецького підприємства «ОЛНОВА» (DP 660-E стаціонарна, електрична), яка призначена для подрібнення відходів деревообробки типу: горбиль, рейка, обапіл, а також гілок і зрізаних дерев (рис. 2). Добре себе зарекомендували під час прибирання лісопосадок, санітарних зон великих міст, розчищенні ліній електроме- реж, та подальшої переробки матеріалу в технологічну та паливну тріску. Виготовляються в стаціонарному та начіпному варіантах. Максимальний розмір подрібнювальних деревних відходів у діаметрі до 160 мм будь-якої довжини. Продуктивність до $8 \mathrm{~m}^{3} /$ год, залежно від типу подрібнювального матеріалу. Можливість регулювання розмірів фракції тріски на виході від 5 до 40 мм.

Вагомим недоліком є велика вартість цієї установки (орієнтовно 4000 доларів). До переваг можна віднести можливість регулювання розмірів фракції тріски на виході.

Проаналізуємо особливості тріскоріза «ТW 13 / 75G CHIPPER», що пропонує англійська компанія «TimberWolf « (рис. 3).

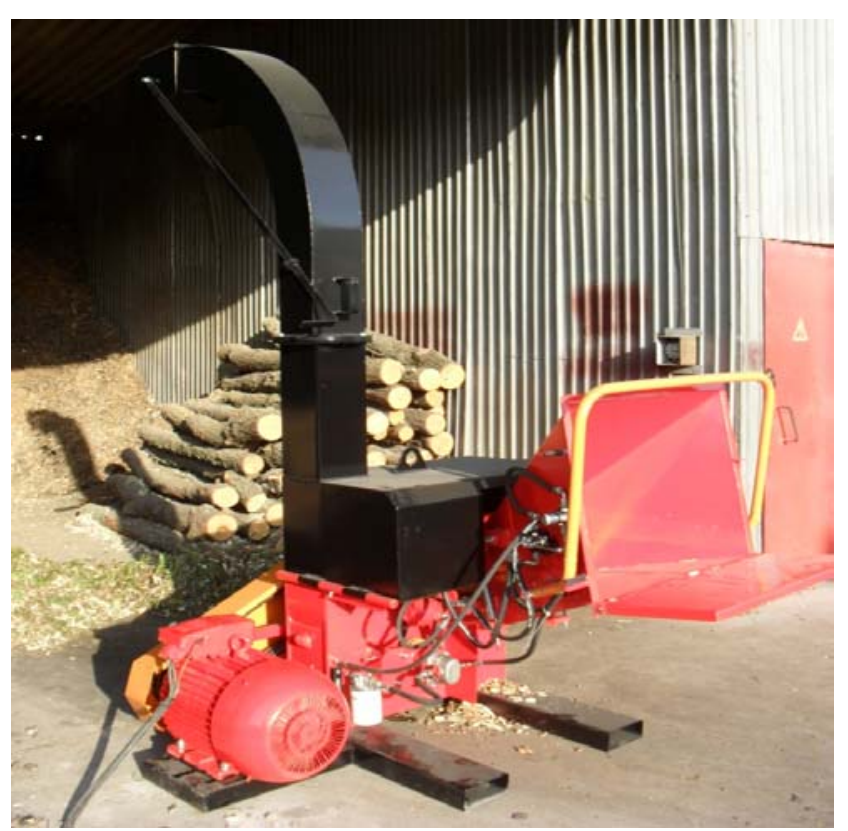

Рис. 2. Деревопереробна машина «DP 660-E»

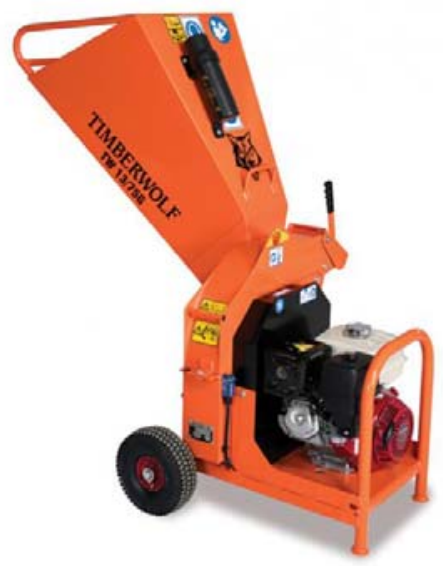

Pис. 3. Tріскоріз «TW 13 / 75G CHIPPER» англійської компанї̈ «TimberWolf» 


\section{TEХНIЧНI НАУКИ}

За допомогою бензинового двигуна Honda 13HP, «Timberwolf TW 13/75G Chipper» призначений для роботи протягом дня, з низькими експлуатаційними витратами. Перевагами конструкції є мобільність, використання власного двигуна. Дисково-ножевий різальний механізм забезпечує подрібнення матеріалу певної фракції, а конструкція лопатей створює повітряний потік для інтенсивного видалення тріски та підвищує продуктивність машини. До недоліків слід віднести високу вартість тріскоріза (орієнтовно 2000 доларів). Діаметр матеріалу, що завантажується у приймальний лоток не повинен перевищувати 75 мм.

Отже, проаналізувавши конструктивні особливості трьох машин можна зробити висновок: конструкція побутової машини для виготовлення паливної тріски заданої фракції в умовах особи-

\section{БІБЛІОГРАФІЯ}

1. Бунецький В. Аналіз технологічних процесів отримання твердого палива у вигляді пелет або брикетів / В. Бунецький // Вісник ЦНЗ АПВ Харківської області: Механізація та електрифікація. - X., 2011. - C. 328-340.

2. Габрель М. Виробництво твердого біопалива в Україні: Стан та перспективи розвитку / М. Габрель // Технологія та устаткування деревообробних підприємств: Науковий вісник НЛТУ України. - Львів, 2011. - С. 126-131.

3. Думич В. Аналіз технологій виробництва різ- стого селянського господарства повинна поєднувати у собі дисково-ножовий робочий орган, калібрувальне решето та мати привід від електродвигуна потужністю від 2 до 3 кВт.

\section{Висновки:}

1. Гранули та пелети з біомаси - екологічний вид палива 3 високою об'ємною теплотворною здатністю. Проте виготовлення гранул - складний, трудомісткий та ресурсовитратний процес.

2. На місцевому локальному рівні в умовах особистих селянських господарств доцільно використовувати біопаливо (тріска), яке не потребує значних витрат на виробництво.

3. Для особистих селянських господарств, слід спроектувати тріскоріз який у своїй конструкції поєднував би переваги промислових машин, за доступну вартість.

них видів твердого біопалива / В. Думич // Науково-виробничий журнал «Техніка і технології АПК». - 2013. - №11 (50). - С. 24-27.

4. ДСТУ ЕN 15234-4:2013 Національний стандарт України. Тверде біопаливо. Забезпечення якості. Частина 4. Тріски деревні для не промислового використання (EN 15234-4:2012, IDT). К. : Мінекономрозвитку України, 2015. - 10 с.

5. Проспекти фірми Heizomat.

6. Так работают немцы! // Woodworking News - новости деревообработки, №3 (111). - 2010. 